\title{
Healthy Eating: Understanding the Nutrition Facts Label ${ }^{1}$
}

Karla P. Shelnutt ${ }^{2}$

\section{Why do we need the nutrition facts label?}

The U.S. Food and Drug Administration requires that most food packages have the Nutrition Facts label. This label contains information about nutrients in the food that can help people make healthier food choices.

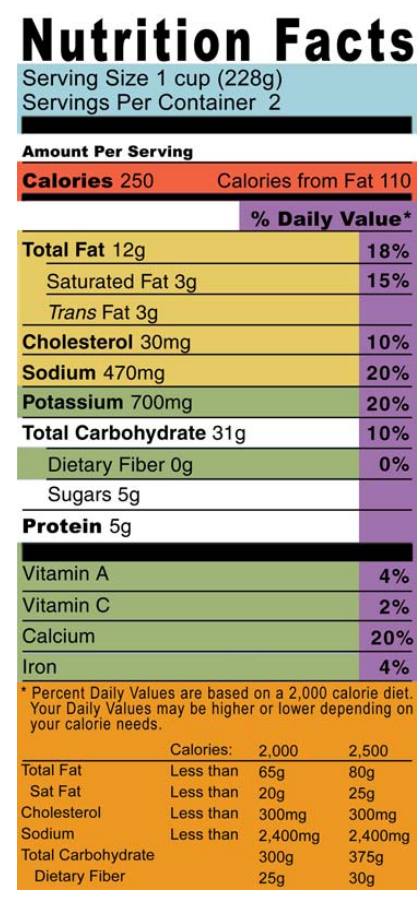

Older adults can use the label to choose foods that fit with a diet plan to manage a certain disease or condition.

For example, persons with hypertension should choose foods lower in sodium, and those with heart disease may need foods lower in fat.

Although the label may look confusing, these guidelines will help you use the information to make better food buying decisions.

\section{Start at the top}

The best place to start is with the serving size and servings per container, located at the top of Nutrition Facts label. Some serving sizes are smaller than what most Americans eat at one sitting. If you eat the whole package, but the serving size on the Nutrition Facts label is only half a package, then you need to double all of the numbers on the label to know how much you have eaten.

\section{Check the calories}

The label tells you how many calories are in one serving. Eating more calories than you need leads to weight gain. Here's a quick guide to understanding the calories:

- 40 calories or less is low

- 100 calories is moderate

- 400 calories or more is high

\section{Limit certain nutrients}

Americans often eat more total fat, saturated fat, trans fat, cholesterol, and sodium than needed in one day. Luckily, these are all listed on the label so you can choose foods that are lower in these nutrients. Aim to eat less than $100 \%$ of the Daily Value for these

1. This document is FCS8883, one of a series of the Department of Family, Youth and Community Sciences, Florida Cooperative Extension Service, Institute of Food and Agricultural Sciences, University of Florida. Publication date:October 2009. Please visit the EDIS Web site at http://edis.ifas.ufl.edu.

2. Karla P. Shelnutt, PhD, RD, ENAFS Program Coordinator, Department of Family, Youth, and Community Sciences, Institute of Food and Agricultural Sciences, College of Agricultural and Life Sciences, University of Florida, Gainesville, FL 32611.

The I nstitute of $\mathrm{F}$ ood and A gricultural S ciences ( IFAS) i s an E qual O pportunity I nstitution aut horized t o pr ovide $r$ esearch, educational information and ot her services only to individuals and institutions that function with non-discrimination with respect to race, creed, color, religion, age, disability, sex, sexual or ientation, marital status, national origin, political opi nions or af filiations. U.S. Department of Agriculture, Cooperative Extension Service, University of Florida, IFAS, Florida A. \& M. University Cooperative Extension Program, and Boards of County Commissioners Cooperating. Millie Ferrer-Chancy, Interim Dean. 
nutrients per day. For a 2,000 calorie diet you should be getting less than the following amounts on a daily basis:

- $65 \mathrm{~g}$ total fat

- 20 g saturated fat

- $300 \mathrm{mg}$ cholesterol

- $2400 \mathrm{mg}$ sodium

\section{Get plenty of good stuff!}

Most American diets don't contain enough fiber, vitamin A, vitamin C, calcium or iron. That's why these nutrients are included on the label. Aim to get at least $100 \%$ of the $\%$ Daily Value for these nutrients each day, especially fiber and calcium. Foods such as fruits,

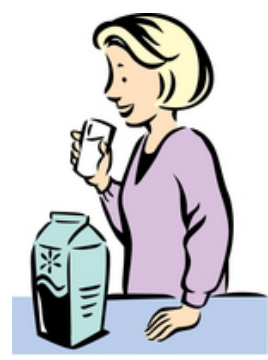
vegetables, whole grains, and low-fat dairy products are great sources of these nutrients.

\section{Look at the \% Daily Values}

The $\%$ Daily Values (\% DV) tell you what percentage of your daily requirement for a nutrient is one serving of a food. The $\%$ DVs are based on a 2,000 calorie diet, but you can use them as a guide even if you need more or less calories. For example, if a food has $50 \% \mathrm{DV}$ for calcium, two servings would provide your total calcium requirement for the day. Of course, we don't need to get $100 \%$ of the DV for any nutrient from one food!

\section{$5 \%$ DV or less is low $20 \%$ DV or more is high}

You can use the \% DV to compare nutrients in different brands of the same kind of food as long as the serving sizes are similar.

\section{What about trans fat, protein, and sugars?}

Even though these nutrients do not have $\%$ DV listed you still can see how much of these nutrients are in a serving of that food item. Experts recommend keeping your intake of trans fats low because they raise blood cholesterol levels.

Older adults need to have enough protein in their diets to stay healthy. Some older adults may not eat enough protein. Go to http://www.MyPyramid.gov for a protein intake recommendation based on your individual needs as well as examples of different types of foods that are great sources of this essential nutrient!

There are no recommendations for sugar intake. The amount of sugar listed on the label includes natural and added sugars. Read the ingredients list to see which sugars are in the food. Some common sugars include: syrups, such as high fructose corn syrup (HFCS), maltodextrin, sucrose, fruit juice concentrate, and fruit juice concentrate. There is growing evidence that too much HFCS may increase the risk for obesity and diabetes, so it's a good idea to avoid eating too much.

For a more detailed explanation of the food label visit the FDA Web site: http://www.cfsan.fda.gov/ dms/foodlab.html.

\section{Where can I get more information?}

The Family and Consumer Sciences (FCS) agent at your county Extension office may have more written information and classes for you to attend. Also, a registered dietitian (RD) can provide you with reliable information. 